\title{
Canola Interference for Weed Control
}

\author{
M. Asaduzzaman · James E. Pratley • \\ Min An · David J. Luckett · Deirdre Lemerle
}

Received: 23 June 2014/Revised: 11 September 2014/Accepted: 26 September 2014/Published online: 9 October 2014

(c) Springer International Publishing AG 2014

\begin{abstract}
The increased incidence of herbicide-resistant weed species, and the related biological repercussions, poses a major threat to sustainable crop production. Integrated weed management, which involves greater reliance on non-chemical weed management tactics such as crop interference, needs to be included in canola production systems. Crop interference comprises both competition and allelopathy which favour the growth of the crop. This review examines canola plant traits associated with competitiveness and allelopathy. Competitive ability is evaluated by the ability of plant morphological traits to improve access to scarce light, nutrients and water in a limited space. Allelopathy refers to the harmful or beneficial effect of crop biochemicals on neighbouring weed species. Allelochemicals are a subset of secondary metabolites produced from intact living roots and crop residues that differ between cultivars and have specific defensive
\end{abstract}

Endorsed by Jim Pratley.

M. Asaduzzaman $(\bowtie) \cdot$ J. E. Pratley $\cdot$ D. Lemerle

School of Agricultural and Wine Sciences, Faculty of Science,

Charles Sturt University, Wagga Wagga, NSW 2650, Australia

e-mail: masaduzzaman@csu.edu.au

M. Asaduzzaman · J. E. Pratley · M. An ·

D. J. Luckett · D. Lemerle

Graham Centre for Agricultural Innovation (an alliance between Charles Sturt University and NSW Department of Primary

Industries), Wagga Wagga, NSW 2650, Australia

M. An

Faculty of Science, Charles Sturt University, Wagga Wagga,

NSW 2650, Australia

D. J. Luckett

NSW Department of Primary Industries, Wagga Wagga,

NSW 2650, Australia functions in the rhizosphere. Elite allelopathic cultivars can be identified by screening canola germplasm. The identification of the allelochemicals involved and their effects in the field also need to be explored. The impact of genetic variation, the mechanisms of allelopathic action, the source and fate of allelochemicals and associated biota in the rhizosphere all need to be considered in new cultivar development. The breeding of weed-suppressive allelopathic canola cultivars needs to be in the context of good agronomic performance. Although allelopathic canola cultivars are unlikely to eliminate all weed pressures in the field, the extent to which they contribute in weed management is worthy of exploration. It remains to be known whether combined competitive and allelopathic cultivars can be developed to maximise overall interference. The integration of agronomic practises with canola interference also needs to be developed.

Keywords Competition - Allelopathy · Root exudates · Rhizosphere $\cdot$ Metabolites

\section{Introduction}

Canola (Brassica napus L.) is a member of Brassicaceae family with low glucosinolates and erucic acid content relative to traditional rapeseed (B. napus $\mathrm{L}$.). It is a major oilseed crop, ranked as the second most important global source of vegetable oil [131]. Canola is also a potential source of specific protein and industrial raw materials including biopolymers, surfactants, adhesives and, more recently, biodiesel [170]. The annual worldwide increase in canola production has been substantial and it is predicted to exceed 15 million tonnes by 2015 [28, 29]. Australia is the world's second largest exporter of canola seed after Canada 
and canola is Australia's third largest broad-acre crop after wheat and barley. The Australian Oilseed Federation [5] predicts that prospects for the Australian canola industry are excellent due to good commodity prices, market demand and its value in the farming system. Canola is, therefore, an attractive alternative crop for grain growers. The rapidly growing demand for canola worldwide implies both greater yield and greater area of production, utilising better management practises and improved cultivars.

Weeds commonly occur in canola crops [95] and their infestation is a major yield-reducing factor [139]. Weeds interfere with crop plants, causing serious impacts as a result of competition for either above or below-ground resources [113]. Canola is exposed to severe competition from weeds which are often considered as the most yield limiting factor in Canada [155]. In India, Gill et al. [63] reported that the magnitude of loss from weeds ranged from 30 to $50 \%$, depending on the growth and persistence of the weed population in the standing crop. Grass weeds, such as annual ryegrass (Lolium rigidum), vulpia (Vulpia myuros) and wild oat (Avena fatua) were most abundant in canola crop of south-eastern Australia [95]. Interference may be through severe soil nutrient depletion [173], water and shading.

Weed competition also reduces grain yield and quality and market value of the canola seed. In Canada, Rose and Bell [136] showed that presence of seeds of wild mustard (Sinapis arvensis) and stinkweed (Thlaspi arvensis) in canola seeds mixtures reduced the seed quality of canola by increasing the level of erucic acid in the extracted oil and the glucosinolate content of the remaining meal. In Australia, heavy infestations of wild radish (Raphanus raphanistrum) have reduced canola yields by up to $90 \%$ [22] and such infestations greatly reduced the quality of canola meal both through crop stress and direct seed contamination of harvested product $[33,101]$.

The use of herbicides and herbicide tolerant canola cultivars has increased rapidly in Australia and worldwide. However, the over reliance on herbicides can reduce their effectiveness and lead to the evolution of herbicide-resistant weeds [12]. High population densities of some weed species necessitate the input of more herbicides but the high use of herbicides exacerbates the development of the resistance problem [77, 126]. The widespread use of triazine-tolerant (TT) canola cultivars has increased the use of triazine herbicides and has led to increased triazineresistant populations of wild radish in Australia [72]. The escalating problem of herbicide-resistant weeds is a challenge to farmers as is the need to manage agrochemicals to minimise soil herbicide residues that can negatively impact on succeeding crops.

Integrated weed management systems have the potential to reduce herbicide use and their associated costs where there is greater reliance on non-chemical control tactics including enhancing crop interferences. It has been shown that the reliability of herbicide performance can be improved when combined with crop species or varieties of superior competitiveness [37, 91].

Interference is the term used to describe an induced effect by an individual plant on a neighbour through changes in the immediate environment [70]. It comprises competition and allelopathy. Zimdahl [173] reported that it is the total adverse effect that both plants exert on each other when growing in a common ecosystem. Competition is the negative interaction between two or more plant species for existence and superiority within a limited space [47]. Competition is greatest when available resources for both crop and weed are below the combined demand [47]. The phenomenon occurs between individuals of the same species (intra-species) and between individuals of different species (inter-species). Allelopathy is distinct from other negative plant interference in that the detrimental effect is through release of chemicals by a donor plant [133]. Molisch [109] indicated that this chemical interference can be both harmful and beneficial. At high concentrations allelopathic chemicals can act as inhibitors while at low concentrations they can sometimes stimulate neighbouring plant growth [110]. Weed responses to crop allelopathy have become well documented in recent decades [129, 135]. However, the impact varies depending on the plant species, cultivar, growth stage and various stress factors. In this review, we examine both forms of canola interference, competition and allelopathy, and discuss possible ways to maximise this beneficial attribute for improved weed control.

\section{Competition}

Crops and weeds compete for various resources. The competitive ability of a particular plant is a major factor in suppressing the competitor. An increase in the biomass and/or population density of one species is the most likely route to increase competition for resources and thus influence the growth and survival of the affected species [154]. Competition for resources between species occurs through both above and below-ground interaction. The competitive ability of a plant is an integrated response over time, with contributions from a range of traits.

\section{Above-Ground Competition for Light and Related Canola Traits}

Light is an essential determinant of the energy balance of the soil and plant, and it drives water and nutrient transport [10]. Competition for light occurs in most cropping situations soon after seedling emergence [48, 131]. Plants 
intercept light using different light attributing characters and a successful plant is not necessarily the plant with more foliage but the plant with foliage in an advantageous position for light interception relative to that of its competitors [47]. Leaves are the principal source of assimilate production during the vegetative phase. In rapeseed $(B$. napus), the lower leaves have been shown to export assimilates basipetally, while the upper leaves exported assimilates almost exclusively acropetally [102]. They translocated and re-translocated the mobile nutrients in the plant system before they senesced [144]. Leaves of rapeseed exerted and developed source-sink capacity during the early growth stage, the expansion rate of leaves being positively correlated with seed yield $[38,153]$. Thus, during early development, light interception by the rapeseed plant influences growth rate that determines competitiveness with neighbours. Plant height, leaf size, number and leaf area index are directly related to the interception of radiation by leaves. In Canada, Beckie et al. [13] indentified from field observations that canola height was as an important criterion of plant competitiveness for resources. Daugovish et al. [41] confirmed that the greater competitive ability of wild oat or yellow mustard over canola was attributed to greater plant growth rate and plant height.

Other plant morphological traits such as stem elongation, upward leaf movement $[21,61,110,124]$ and leaf layer density [46] all contribute to competitiveness for light. These plant components usually relate to shade avoidance, allowing plants to photosynthesise and grow to become more competitive $[11,21,124]$. Further, the variation in morphological sensitivity of plants to light signals is known to vary among cultivars [86]. Thus, choice of a suitable shade-avoidance cultivar, combined with agronomic tactics (e.g. crop density and row arrangement), also helps to manipulate crop plant photomorphogenesis. In Australia, vigorous hybrid canolas have generally been shown to compete more successfully with, for example, annual ryegrass than did TT canola varieties [93]. The plant biomass measures of both cultivar types were negatively correlated with weed plant biomass [93]. The study was consistent with Canadian results that suitable vigorous hybrid genotypes provide more competition against weeds $[68,69$, 171]. Vigorous hybrids produce tall plants with much foliage, thereby reducing light penetration to the weed canopy. Choice of vigorous cultivars can be an effective crop interference tactic for weed management especially in the early establishment phase of a canola crop.

Below-Ground Competition for Nutrients and Water and Associated Canola Traits

Competition for below-ground resources constitutes an important aspect of crop-weed interaction. This below- ground interference has been reported to reduce plant performance more than do above-ground relations [165]. Below-ground competition usually occurs for space, soil nutrients and water. Plants take up soil nutrients mainly by diffusion and mass flow mechanisms from the depletion zone (the concentration gradient surrounding the roots) [118]. The competitive ability of a crop plant is likely determined by its capacity to make use of nutrients from this zone [47] and plants usually invest relatively more resources into roots compared with shoots for belowground competition [125]. Efficient nutrient acquisition by roots becomes an important key for plant competitive ability. Characteristics related to nutrient and water uptake include plant root size and depth, relative growth rate, biomass, root density and total surface area $[1,2,31,55]$. The canola plant has an extensive root system [161] with abundant root hairs [66] to give it high root surface area and large potential to extract nutrients from the soil [66]. Strong and Soper [152] reported that roots of Brassica plants proliferate in areas of high nutrient concentration, although differences exist among genotypes in their ability for nutrient acquisition. Nitrogen uptake by canola, for example, has been linked to total root biomass rather than higher uptake per unit of length [81]. However, Laine et al. [89] demonstrated that if one half of the canola root system was starved of nitrogen, the other half was still able to supply the shoot with sufficient nitrogen through increased uptake per unit of root length. The optimisation of canola root traits for nutrient acquisition may link with its competitive ability against different weed species.

The conversion of soil resources to plant biomass (referred to as nutrient use efficiency) differs between species and cultivars [31]. A typical canola plant usually has a higher demand for phosphorus and potassium than does a wheat plant $[29,137,152]$. These demands may influence success in gaining a greater share of the other nutrients to establish dominance over a less successful weed species. Duan et al. [50] reported that the rate of root biomass accumulation in canola was positively correlated with increased lateral root length [50] while, in another study, canola biomass was negatively correlated with weed biomass [92]. The biomass of canola was regulated by the reduced $\mathrm{pH}$ in the rhizosphere resulting from the release of organic acids by its roots [50]. In soil, insoluble phosphorus usually becomes more readily available to canola roots through the acidification of soil near the rhizosphere [2, 73, 138]. Understanding the process involved in the acquisition of soil resources, and the associated mechanisms by which canola competes, may help improve the below-ground competitive ability of canola for nutrient acquisition in the presence of weeds.

Plants provide a pathway for water movement between the soil and the atmosphere. This path begins in the soil 
with water uptake and is influenced by numerous biotic and abiotic factors [31]. Plants experience competition for water when the moisture supply in the soil environment is reduced (e.g. uptake by neighbour) or is exceeded by the evaporative demand [130]. Donald [47] asserted that the success of any cereal plant for water competition depends on the rate and completeness with which it can make use of the soil water supply. This capacity for water uptake by crops is determined by several attributes within the environment such as transpiration rate and stomatal resistance capacity $[31,78]$ and the efficiency of water use by plant roots and leaves [75]. Poor stomatal control, for example, results in relatively high plant water use and this may increase competitiveness if the plant neighbours are water conservers [130]. In canola, it is assumed that hybrid cultivars with early vigour use available soil water more quickly, thereby making it relatively unavailable for use by neighbouring weeds. The competitive ability of a cultivar may increase in a specific location due to the environmental influence on evapotranspiration. Although the mechanisms were not clear, it has been suggested that in cool environments hybrid canola induces non-favorable conditions for weed growth by reducing soil resources [68]. Essential nutrients, once inside the canola plant, can be relocated to support growth and, advantageously, they are, therefore, not available to neighbouring weed species.

Plant avoidance and tolerance mechanisms to soil water stress are related to its root morphology and distribution. Pavlychenko and Harrington [122] found that the considerable depth of the root systems of wheat provided good adaption for drought tolerance and weed competition. Likewise in canola, a deep root system is likely a key trait of the plant's ability to access sufficient water. Canola roots have been shown to extract water from a depth of $150 \mathrm{~cm}$ although up to $95 \%$ of the total seasonal uptake was removed from the top $105 \mathrm{~cm}$ of the soil profile [114]. Thus, cultivars with a deep root system trait may become more competitive by being able to adjust their avoidance or tolerance of soil water stress. Roots of canola and other Brassica species, however, are poorly adapted to dry regions and so agronomic adjustment of these early-seeding or early-maturing cultivars may be needed to improve tolerance to competition through better water use efficiency during the seed filling stage. In Western Australia, the early sowing and early flowering cultivars of $B$. napus produced the greatest total dry weight and seed yield due to efficient water use compared with a late sowing [153]. Early flowering cultivars also showed better competitive ability in Canada because they proliferated their root systems as soon as they sensed a water source, enabling them to fully utilise those resources [32]. These data demonstrate key aspects of canola roots in competitive interference: tolerance of water stress without changes in physiological adaption; and canola root architecture and cellular mechanisms.

\section{Selecting a Competitive Canola Ideotype}

The crop ideotype consists of morphological and physiological traits which contribute to enhanced yield relative to currently prevalent crop cultivars. Such a plant will make minimum demand on resources per unit of dry matter production [48]. The design of crop ideotypes, however, may likely involve modifications related to the environment. An evaluation of the competitive ability of different cereal crops, such as rice, wheat and barley, clearly showed that no one ideotype was appropriate for every environment [168]. Different combinations of plant traits could confer the best competitive advantage depending on growing season, climatic conditions and competitiveness with weed species as well as the timing of the competition [168]. Olofsdotter et al. [119] reported that the best competitive plants also have good biotic and abiotic stress resistance. Little consideration has been given to the inclusion of specific plant traits for strong competiveness with weeds to enhance yield stability. Understanding which traits are most strongly associated with competitive advantage of canola is important for developing new cultivars and should include allelopathy in the development of a canola ideotype.

\section{Allelopathy}

The term allelopathy originated from the Greek word "allelon" meaning each other and "pathos" meaning suffering and was first introduced by Austrian plant physiologist Molisch [109]. The word "pathos" also means "feeling" or "sensitive" and could, therefore, be used to describe both positive (sympathetic) and negative (pathetic) interactions [65]. The concept of allelopathy received further attention by Rice [132]. He defined allelopathy as an important mechanism of plant interference mediated by the addition of plant-produced secondary products into the rhizosphere [133]. The organic secondary products involved in inhibitory or stimulatory effects are referred to as allelochemicals and these can be released through volatilisation, leaching from plant leaves, residue decomposition and active root exudation [36, 133]. Chemicals with allelopathic potential are present in nearly all plants and their respective tissues [164]. Under the appropriate environmental conditions, these phytotoxic compounds may be released into the environment in sufficient quantities to affect the growth of neighbouring plants [163]. Allelopathy is a significant component of crop/weed interference and, therefore, a potential weed 
management tool $[15,82,117]$. Allelopathy includes the use of phytotoxic chemicals released from crop residues as well as from intact roots of living plants [163, 164].

\section{Allelopathy of Canola Residues}

Crop allelopathy evidence initially came from studies of the use of organic mulches and cover crops to suppress weed emergence. The presence of growth inhibiting substances in plant residues was reported by Collinson [39]. The decomposition products of residues can exert effects on weed germination and establishment [14, 107, 127, 128, 163] either taken up by the recipient singly, additively or synergistically [54], adsorbed onto soil colloids [40], modified or reduced or biochemically modified (including non-toxic chemicals into toxic chemicals) by soil organisms $[58,147]$. These inhibitory allelopathic effects of residues of both native and cultivated Brassica spp and their relatives have been reported for weed suppression. Boydston and Hang [24] reported that residues of soil-incorporated foliage of canola suppressed plant populations of common lambsquarters (Chenopodium album), redroot pigweed (Amaranthus retroflexus), barnyard grass (Echinochloa. crus-galli), hairy nightshade (Solanum sarrachoides) and longspine sandbur (Cenchrus longispinus [Hack.] Fern.) [24]. In Australia, Jones et al. [80] reported that residues of barley, wheat and canola showed adverse effects on the survivability, growth and dry matter production of paradox grass (Phalaris paradoxa), wild oat (A. fatua) and turnip weed (Rapistrum rugosum). Several subsequent weed suppression studies showed that Brassica cover crops, such as rapeseed and mustard, have high potential to be used in an alternative weed management system. The researchers concluded that an allelopathic mechanism was involved [3, $24,25,85,158]$. Tissue damage and then hydrolysis of the Brassica plants released glucosinolate breakdown products, including isothiocyanates, oxazolidinethiones, ionic thiocyanate (SCN-) and organic cyanides [25, 67]. Most breakdown products of glucosinolates are volatile, whereas hydroxamic acids are water-soluble. In the soil, hydroxamic acids can be transformed into more toxic compounds by neighbouring weed species [59, 62]. Although the specific modes of action of these compounds on target weed species have not been thoroughly investigated, most compounds showed inhibitory effects on other species through reduced and delayed germination or inhibition of seedling emergence $[115,116]$. The level and the time course of allelochemical release and of other residue-mediated alterations in the soil are largely dependent on the amount and decomposability of the residue, on soil biological, chemical and physical characteristics [34, 96] or on residue management practises [88]. It is unclear whether canola living roots release these compounds in exudation or whether release occurs only during decomposition, and it is worthy of further investigation.

\section{Biofumigation}

Biofumigation is defined as the use of biocidal compounds, primarily isothiocyanates, used as commercial fumigants, or released by Brassicaceous plants used as green manure or rotation crops, for suppression of soil-borne pests and pathogen [4, 83]. Such compounds have relatively high vapour pressure and are thoroughly dispersed throughout the surrounding soil where they may affect soil-borne fungi, pathogen, insects and nematodes [111]. This finding has led to an increased interest in the development of biofumigation strategies, where naturally formed isothiocyanates could be used as a control measures. Incorporation of Brassicaceous plants in order to control pathogens and nematodes has proven to be effective in several studies [108, 112]. The use of canola as a break crop to help control take-all fungus (Gaeumannomyces graminis) in cereal rotations in Australia is also an example of this biofumigation effect. However, the inconsistent results in biofumigation studies (reviewed by Matthiessen and Kirkegaard) [103] implied that other factors were involved. The profile of isothiocyanate production varies between Brassica species [84, 142, 143, 149, 159], between individuals of the same genotype [53, 84], and even within different plant tissues of a single individual [57, 104]. Furthermore, it needs to be considered that there are beneficial organisms including biocontrol agents, that are also affected by glucosinolate breakdown products and their presence may have consequences for pest control in an integrated pest management (IPM) agro-ecosystem. The existence of the biofumigation capability, however, is demonstrative of the potential of root exudation for crop management. Their role for weed control remains to be evaluated fully.

\section{Canola Allelopathy by Intact Roots of Living Plants}

Weed suppression via living plant exudation is considered a promising approach to exploit allelopathy in annual crops $[7,51,52,134]$. Belz $[15,16]$ claimed that weed suppression by crop plant root exudation is a valuable mechanism if this trait can be exploited in much the same way as defence mechanisms against insects or pathogens. The approach has already been reviewed for major grain crops including rice $[45,145]$, wheat $[17,169]$ and barley [17, $18,97]$. Those reviews showed that the allelopathic ability of a crop plant to defend itself against weeds was possible and there was considerable genetic variability to exploit such mechanism among cultivars. The family Brassicaceae 
is often reported as having allelopathic properties that can affect establishment and growth of other species by root exudation [14, 98, 156]. An intercropping study between wild mustard and broccoli demonstrated that broccoli yield was reduced by $50 \%$ due to the phytotoxic effect of plant exudation from wild mustard [79]. In the USA, cultivated or naturally occurring mustards often formed relatively pure stands when well established and, in the wild, they can be successful invaders of native grasslands [14, 163]. In Turkey, Uremis et al. [156] found that root exudates of the rapeseed cultivar Westar influenced the root growth of redroot pigweed (A. retroflexus L.), black nightshade (Solanum nigrum L.), common purslane (Portulaca oleracea L.), cutleaf ground cherry (Physalis angulata L.) and jungle rice (Echinochloa colonum) more than shoot growth, whereas other cultivars Jumbuck, Tobin, Lisoune and Galant showed less allelopathic activity through their root-secreted chemicals. This suggests that canola plants are also likely to show allelopathy through root exudation and raises the prospects of creating elite allelopathic canola genotypes with improved weed-suppressive capability.

\section{Canola Root Exudates and Phyto-Chemistry}

Plant living root hairs and actively growing primary and secondary roots typically release large quantities of secondary metabolites (known as root exudates) [19]. This phenomenon has long been regarded as a passive process of secreted photosynthetically fixed carbon into the soil [9]. Root exudates or secondary metabolites represent one of the largest direct inputs of plant chemicals into the rhizosphere and almost certainly root exudates comprise the major sources of allelochemicals [19]. Stressed plants secrete particular secondary metabolites for their defensive activity [6, 162]. For example, Arabidopsis thaliana (Brassicaceae) secretes a large number of defence metabolites when grown alone [6]. However, once a plant neighbour is identified, the repertoire of metabolites is reduced but overall their secretion increases significantly [6]. In addition to the role in plant defence, some metabolites have physiological functions by serving as mobile and toxic nitrogen transport and storage compounds [166, 167]. However, these multiple functions do not compromise the main role of secondary metabolites as chemical defence and signalling compounds [166].

Exuded compounds are highly species-specific. They move safely into the environment through a variety of plant sequestration (e.g. sub-cellular vesicles) and transport mechanisms (e.g. protein embedded) [9, 19, 162]. Allelopathy in Brassica spp. appears to be associated with the presence of several groups of exudated metabolites such as phenylpropanoid, flavonoids, isothiocyanates and glucosinolates [26, 85, 90, 115, 116, 119, 121, 166]. These sulphur-containing compounds are indole derivatives at the C-3 position of the indole ring [44, 123]. Phenylpropanoids have a wide variety of functions including defence against microbial attack and other sources of injury [74]. Glucosinolates provide pathogenic organism defence [106] and can accumulate and modify to yield a variety of products including isothiocyanates, thiocyanates and nitriles but this depends on the nature of glucosinolates and the stress imposed [35, 105]. Choesin and Boerner [35] measured the direct release of isothiocyanate from growing the root of $B$. napus but they did not evaluate its effect on weed species.

Research is needed to clarify the type of chemicals released by intact canola roots and their role in weed inhibition. Such findings would facilitate investigation of the biochemistry and metabolomic pathways of these chemicals in plants in respect of canola allelopathy. It would also provide opportunities for new weed controlling cultivars.

\section{Root Exudates and Rhizosphere Communication}

The rhizosphere is the narrow region of soil directly influenced by root secretions and associated soil biota [19, 157]. In this zone, plant root-secreted chemicals can influence several processes such as resources (e.g. soil nutrients) and non-resource plant-mediated interaction [133], microbial communities and their populations [9] and neighbouring plant species [147]. These influences may play an important role in communication between other plants in the rhizosphere [160].

\section{Root-Microbes Communication}

Survival of a plant species in a particular rhizosphere depends on the mechanisms of adaption to interaction with biotic and abiotic components. The root rhizosphere is considered the place that provides habitat for plant roots and microorganisms and is inhabited by a wide range of microorganisms, including bacteria, fungi, algae, viruses and protozoa. These microbes may have a profound effect on allelopathic activity by altering and/or transforming the amount of allelochemicals [153]. On the other hand, allelochemicals may also influence the microbial community [71, 87] and these mechanisms can involve both stimulation (by providing nutrient sources) and inhibition (by interfering with nutrients) [124]. Various soil-borne organisms are highly sensitive to the Brassica plantsecreted 2-phenylethyl isothiocyanate, with bacteria being more tolerant than eukaryotic organisms [150]. In contrast, 
growth of ectomycorrhizal fungi was found to be stimulated by root exudates of various Brassica spp. [172]. Rumberger and Marschner [140, 141] reported that canola roots released sufficient amounts of 2-phenylethyl isothiocyanate into the soil rhizosphere to have a selective effect on the bacterial community. Bacterial community composition was significantly correlated with phenylethyl isothiocyanate concentration and moreover changed with plant growth stage [140, 141]. However, despite high residence time of this chemical, Choesin and Boerner [35] found in their study that this root secretion did not have an inhibitory effect on Medicago sativa L. This suggests that specific signals might be exchanged between Brassica plants and microorganisms, although this is not yet clear. It would be also interesting to know whether the possible allelopathic chemicals described for canola roots act directly against the neighbouring plants or indirectly through modifications by soil microorganisms.

\section{Root-Root Communication}

Crop plant roots are continually interacting with roots of neighbouring plant species; and are capable of detecting and responding in multiple ways [20, 42, 56, 99, 148]. Roots may communicate with other roots with the help of various secondary metabolites, which are secreted into the rhizosphere in response to biotic and abiotic stresses.

Several research studies suggest that such a response of roots to their neighbours is not only explained by nutrients but also involves non-nutrient causes [8, 9]. Cahill and McNickle [27] divided these apparent non-nutrient root responses into three classes: (a) segregation (root growth away from neighbours), (b) neutral (no specific directionality of root growth) and (c) aggregation (root growth towards neighbouring roots). The actual sensing of the neighbour presence might be based on either physical touching of roots [100] or without physical touching via chemicals signals released by roots $[6,76]$. For chemical signals, secondary metabolites have been largely credited with being involved in plant-plant interaction on the assumption that these compounds tend to be phytotoxic and persist in the soil [6]. Of course, such compounds could be hormonal or pseudo-hormonal in their influence on nonsame neighbours. Pierik et al. [124] reported that the high specificity of root exudates has the potential to transport such specific signals into the rhizosphere. It has been reported that the proteins in the root exudates are secreted differently depending upon the presence and identity of the neighbouring root $[6,43]$. Such canola-neighbour root interactions have not been elucidated. Establishing these interactive mechanisms by canola exudates will elucidate the true complexity of the competitive arena (Fig. 1).

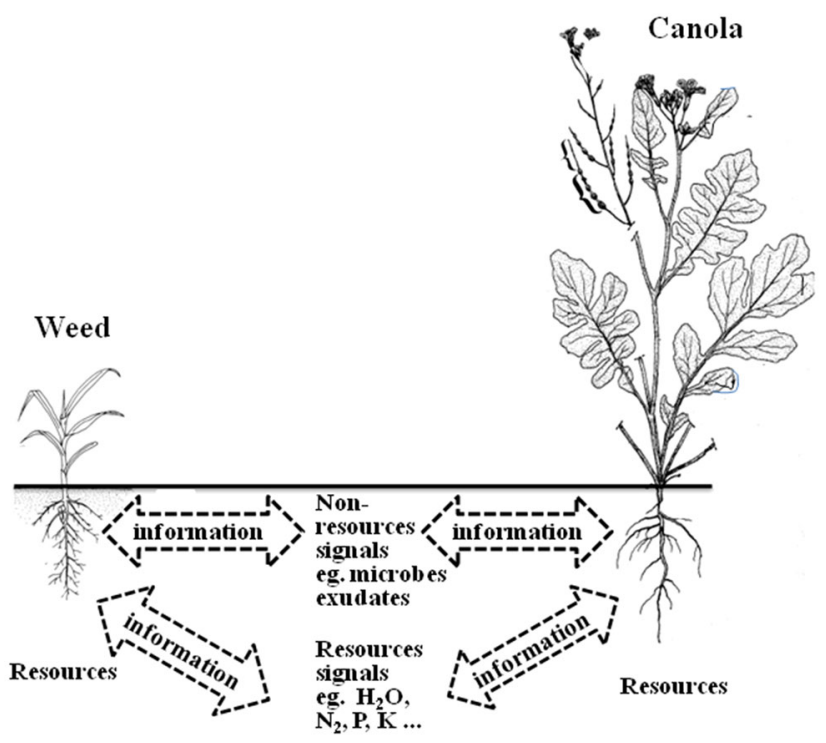

Fig. 1 Canola-weed below-ground interactions (resources and nonresources based) involve various signals, such as variations in nutrient concentrations, soluble root exudates and the activities of soil microbes

\section{Conclusions}

Herbicide-resistant weeds can increase the cost of canola production and reduce yields. Weeds may become a greater economic issue, if non-chemical weed management tactics are ignored. To maintain a sustainable production system and effectively manage the weed burden, an integrated weed management program incorporating crop interference needs to be included in the canola crop production system. The implementation of a high interference strategy for canola in the field requires a fuller understanding of canola competition and allelopathy on weeds. This includes a greater knowledge of the response of plants to their environment and to the stresses created by neighbouring weeds. Such elucidation will help to understand which traits matter under which conditions. Understanding the regulatory mechanisms that enable an individual canola plant to optimise these traits is a key to understanding canola-weed competition. The need for further experimentation to estimate accurately the relative ranking of current canola varieties for competitive ability at regional level is desirable. Evidence thus far suggests that some varieties are consistently more competitive than others, but considerable environmental variation exists, making reliable recommendations for farmers difficult. Growing vigorous crops by the many means possible is the challenge [94]. Changing farming practises, such as the move from conventional cultivation to reduced tillage and stubble retention systems, may influence weed growth and population dynamics [30]. More research is needed to determine the 
impact of variety competitive ability on weed seed production for population dynamics modelling, particularly with respect to closely related weed species such as wild radish and wild mustard, to assist in predicting the longterm benefits of integrated weed management in a canola production system.

Communication between canola shoots and the roots is also important to ensure the shoot is adequately receiving below-ground resources for enhancing above-ground competition. Potential already seems to exist for breeding enhanced canola competitive ability through greater early vigour and below-ground root characteristics. Competitiveness of canola can be increased by breeding for suitable plant traits and by manipulation of the management system but the benefits and costs of crop competitive ability need to be evaluated. The competitive ability of a specific genotype in a particular environment may be much lower in another environment.

Increasingly, studies reveal that non-resources crop interference such as allelopathy plays an important role in some crop species. This opens the possibility to explore and utilise canola allelopathy. Below-ground plant-plant competition is more complex than above-ground and interdisciplinary research is needed to enable thorough understanding of canola allelopathy.

The role of chemical signals between canola and other organism in the rhizosphere needs further study. The same chemical signal may deter one organism while attracting another [7]. Plants rarely secrete just one substance and so there may be a blend of potential signals from molecules which are highly selective $[49,124]$. In addition, ecological knowledge indicates that below-ground interactions could potentially be transformed to above-ground responses in plants. Integration of the different technology platforms are needed to understand the complex network of canola plant responses to various external factors including regulation via various signalling pathways.

In order to evaluate to what extent canola contributes in the crop-weed interference mechanism, the first task is to evaluate the existence of genetic variation of allelopathy in canola under laboratory conditions. Crop laboratory bioassays can demonstrate the potential chemical interference among crop cultivars within a limited time frame. Interestingly, much effort has been put into the development of sound screening protocols and most existing screening techniques are reliable, fast, cheap and space limited.

Laboratory bioassays are also suitable for understanding different aspects of allelopathy (e.g. release of chemicals from the donor plant, fate and persistence in soil, growth and uptake of allelochemicals) [23, 60] but it is also important to know the fate of these chemical compounds in the soil and their interaction with abiotic and biotic influences. The outcomes of this research should address the sources of variation in allelopathy between cultivars. The bioactivity of the chemicals released by intact roots, however, may be compromised by an allelopathic species and could be rendered unavailable by the combined interactions of soil texture, organic matter, temperature and soil microbes $[9,64,151]$. The exudation of these compounds will determine the allelopathic effect. In the field, allelopathic effects are difficult to measure [120] and dependence on parallel in vitro experiments is required. Seal et al. [146] found that laboratory screened allelopathic rice cultivars performed well in the field and proved to be active against multiple weed species. More recently, field testing has been expanded from rice to wheat and barley.

Discovery of the allelochemicals involved in interference is essential by both traditional and advanced metabolomics methods (with HPLC, IR, GC/LC MS-QTOF and NMR etc.). Metabolomics is an important tool for an unbiased view of metabolites with combined principal components analysis. If canola cultivars produce and release sufficient amounts of herbicidal compounds, then the biochemistry of the exudation process needs to be understood.

Study of the genetic control of the allelopathic traits is important for the development of competitive canola varieties. In a study of allelopathic activity of population of $400 \mathrm{~F}_{2}$ rice plants on duck salad (Heteranthera limosa), Dilday et al. [45] found that rice allelopathic activity was normally distributed, suggesting that the rice allelopathic trait was quantitatively inherited. The genetic study of allelopathy is still in its infancy but it does represent a promising new frontier for future research. Modern methodologies in molecular genetics and biochemistry have made this type of research more rapid and more direct than in the past. To develop high-yielding commercial canola cultivars with elevated allelopathic activity without sacrificing other agronomic traits, breeders' time and resources should be allocated after confirmation of significant crop allelopathic performance in the field. Allelopathy alone is unlikely to control all weeds but its enhancement will be a potential contributor for a sustainable integrated weed management system.

Acknowledgments The senior author is grateful to Charles Sturt University, Australia for the award of an International Post Graduate Research Scholarship, an Australian Postgraduate Award research scholarship and the prestigious Writing up Award. He is indebted to the Department of Agronomy of Sher-e-Bangla Agricultural University, Dhaka, Bangladesh for allowing him study leave to do his $\mathrm{PhD}$ study at Charles Sturt University Wagga Wagga, NSW Australia.

\section{References}

1. Aarssen LW (1983) Ecological combining ability and competitive combining ability in plants: toward a general evolutionary 
theory of coexistence in systems of competition. Am Nat 122:707-731

2. Akhtar MS, Oki Y, Adachi T (2008) Genetic variability in phosphorus acquisition and utilization efficiency from sparingly soluble P-sources by Brassica cultivars under P-stress environment. J Agron Crop Sci 194:380-392

3. Al-Khatib K, Libbey C, Boydston RA (1997) Weed suppression with Brassica green manure crops in green pea. Weed Sci 45(3):439-445

4. Angus J, Gardner P, Kirkegaard JA, Desmarchelier J (1994) Biofumigation: isothiocyanates released from Brassica roots inhibit growth of the take-all fungus. Plant Soil 162(1):107-112

5. AOF (2013) Australian Oilseeds Fedaration Crop Report. pp 1-2. http://www.australianoilseeds.com/about_aof/news/?a= 7963

6. Badri DV, De-la-Pena C, Lei Z, Manter DK, Chaparro JM, Guimaraes RL, Summer LW, Vivanco JM (2012) Root secreted metabolites and proteins are involved in the early events of plant-plant recogniation prior to competition. PLoS ONE 7(10):46640

7. Bais HP, Vepachedu R, Gilroy S, Callaway RM, Vivanco JM (2003) Allelopathy and exotic plant invasion: from molecules and genes to species interactions. Science 301:1377-1380

8. Bais HP, Walker TS, Stermitz FR, Hufbauer RA, Vivanco JM (2002) Enantiomeric-dependent phytotoxic and antimicrobial activity of $( \pm)$-catechin. A rhizosecreted racemic mixture from spotted knapweed. Plant Physiol 128:1173-1179

9. Bais HP, Weir TL, Perry LG, Gilory S, Vivanco JM (2006) The role of root exudates in rhizosphere interactions with plants and other organisms. Annl Rev Plant Biol 57:233-266

10. Ballare C, Casal JJ (2000) Light signals received by crop and weed plants. Field Crop Res 67:149-160

11. Ballare CL, Scopel AL (1997) Phytochrome signalling in plant canopies: testing its population-level implications with photoreceptor mutants of Arabidopsis. Funct Ecol 11:441-450

12. Beckie HJ, Harker KN, Legere A, Morrison MJ, Swartz GS, Falk KC (2011) GM canola: The Canadian experience. Farm Pol 8:43-49

13. Beckie HJ, Johnson EN, Blackshaw RE, Gan Y (2008) Weed suppression by canola and mustard cultivars. Weed Technol $22: 182-185$

14. Bell DT, Muller CH (1973) Dominance of California annual ryegrass lands by Brassica nigra. Am Midl Nat 90:277-299

15. Belz RG (2004) Evaluation of allelopathic traits in Triticum spp. and Secale cereale. $\mathrm{PhD}$ thesis, University of Hohenheim, Stuttgart, Germany

16. Belz RG (2007) Allelopathy in crop/weed interaction-an update. Pest Manag Sci 63:308-326

17. Bertholdsson NO (2004) Variation in allelopathic activity over one hundred years of barley selection and breeding. Weed Res 44:78-86

18. Bertholdsson NO (2005) Early vigour and allelopathy-two useful traits for enhanced barley and wheat competitiveness against weeds. Weed Res 45:94-102

19. Bertin C, Yang X, Weston L (2003) The role of root exudates and allelochemicals in the rhizosphere. Plant Soil 256:67-83

20. Biedrzycki ML, Bais HP (2010) Kin recognition in plants: a mysterious behaviour unsolved. J Exp Bot 61:4123-4128

21. Blackshaw RE (1994) Differential competitive ability of winter wheat cultivars against downy brome. Agron J 86:649-654

22. Blackshaw RE, Lemerle D, Mailer R, Young KR (2002) Influence of wild radish on yield and quality of canola. Weed Sci 50:344-349

23. Blum U, Shafer SR, Lehman ME (1999) Evidence for inhibitory allelopathic interactions involving phenolic acids in field soils: concepts vs. an experimental model. Critical Rev Plant Sci 18:673-693

24. Boydston RA, Hang A (1995) Rapeseed (Brassica napus) green manure crop suppresses weeds in potato (Solanum tuberosum). Weed Technol 9:669-675

25. Brown PD, Morra MJ (1996) Hydrolysis products of glucosinolates in Brassica naupus tissue as inhibitors of seed germination. Plant Soil 181(2):307-316

26. Brown PD, Morra MJ (1997) Control of soil-borne plant pests using glucosinolate-containing plants. Adva Agron 61:167-231

27. Cahill JF, McNickle GG (2011) The behavioral ecology of nutrient foraging by plants. Annual Rev Ecol Evol Syst 42:289-311

28. Canola Council of Canada (2011) Annual report, growing momentum, Manitoba

29. Canola Council of Canada (2009) Canola oil and meal: standards and regulations, Manitoba

30. Cardina J, Sparrow DH (1996) A comparison of methods to predict weed seedling populations from the soil seedbank. Weed Sci 44:46-51

31. Casper BB, Jackson RB (1997) Plant competition underground. Annu Rev Ecol Syst 28:545-570

32. Chadwick BK (2011) The effect of seedling root length on seed yield in Brassica napus L. Ph D thesis, Department of plant science, University of Manitoba, Canada

33. Cheam AH, Code GR (1995) The biology of Australian weeds Raphanus raphanistrum L. Plant Prot Q 10(1):2-13

34. Cheng HH (1992) A Conceptual framework for assessing allelochemicals in the soil environment: Allelopathy: basic and applied aspects. Chapman \& Hall, London

35. Choesin DN, Boerner REJ (1991) Allyl-isothiocyanate release and the allelopathic potential of Brassica napus (Brassicaceae). Am J Bot 78(8):1083-1090

36. Chou CH (1999) Roles of allelopathy in plant biodiversity and sustainable agriculture. Crit Rev Plant Sci 18:609-636

37. Christensen S (1994) Crop weed competition and herbicide performance. Weed Res 34:29-36

38. Clarke JM, Simpson GM (1978) Growth analysis of Brassica napus cv. Tower. Can J Plant Sci 58:587-595

39. Collinson RC (1925) The presence of certain organic compounds in plant and their relation to the growth of other plants. J Am Soc Agron 17:58-65

40. Corchran VL, Elliot LF, Papendick RI (1977) The production of phytotoxins from the surface crop residues. Soil Sci Soc Am 41:903-908

41. Daugovish O, Thill DC, Shafii B (2002) Competition between wild oat (Avena fatua) and yellow mustard (Sinapis alba) or canola (Brassica napus). Weed Sci 50:587-594

42. de Kroon H (2007) How do roots interact? Science 318:15621563

43. De-la-Pena C, Lei Z, Warson BS, Summer LW, Vivanco JM (2008) Root-microbe communication through protein secretion. J Biol Chem 83:25247-25255

44. Devys MS, Barbier M, Kollmann A, Rouxel T, Bousquet JF (1990) Cyclobrassinin sulphoxide, a sulphur-containing phytoalexin from Brassica juncea. Phytochem 29:1087-1088

45. Dilday R, Yan W, Moldenhauer K, Gravois K (1998) Allelopathic activity in rice for controlling major aquatic weeds: allelopathy in rice. International Rice Research Institute, Manila

46. Donald CM (1961) Mechanisms in biological competition. Society for Experimantal Biology Symposium. Academic press, New York

47. Donald CM (1963) Competition among crop and pasture plants. Adv Agron 15:1-118

48. Donald CM (1968) The breeding of crop ideotypes. Euphytica 17(3):385-403 
49. Doornbos RF, Cornelis LVL, Bakker PAHM (2012) Impact of root exudates and plant defence signalling on bacterial communities in the rhizosphere: a review. Agron Sustain Dev 32:227-243

50. Duan H, Shi L, Ye X, Wang Y, Xu F (2009) Identification of phosphorus efficient germplasm in oilseed rape. J Plant Nutr 32:1148-1163

51. Duke SO, Baerson SR, Rimando AM, Pan Z, Dayan FE, Belz RG (2007) Biocontrol of weeds with allelopathy: conventional and transgenic approaches. Novel biotechnologies for biocontrol agent, enhancement and management NATO Security through Science Series

52. Duke SO, Belz RG, Bearson SR, Pan Z, Cook DD, Dayan FE (2005) The potential for advances in crop allelopathy. Outlook Pest Manag 16:64-68

53. Eberlein CV, Morra MJ, Guttieri MJ, Brown PD, Brown J (1998) Glucosinolate production by five field grown Brassica napus cultivars used as green manures. Weed Technol 12(4):712-718

54. Einhellig FA (1996) Interaction involving allelopathy in cropping system. Agron J 88:886-893

55. Fargione J, Tilman D (2006) Plant species traits and capacity for resource reduction predict yield and abundance under competition in nitrogen-limited grassland. Funct Ecol 20:533-540

56. Falik O, Reides P, Gersani M, Novoplansky A (2003) Self/nonself discrimination in roots. $\mathrm{J}$ Ecol 91:525-531

57. Fieldsend J, Milford G (1994) Changes in glucosinolates during crop development in single- and double-low genotypes of winter oilseed rape (Brassica napus): I. Production and distribution in vegetative tissues and developing pods during development and potential role in the recycling of sulphur within the crop. Ann Appl Biol 124:531-542

58. Fischer HN, Williamson GB, Weidenhamer JD, Richardson DR (1994) In search of allelopathy in the Florida scrub: the role of terpinoids. J Chem Ecol 20:1355-1380

59. Fomsgaard IS, Mortensen AG, Carlsen SCK (2004) Microbial transformation products of benzoxazolinone and benzoxazinone allelochemicals-a review. Chemos 54:1025-1038

60. Foy C (1999) How to make bioassays for allelopathy more relevant to field conditions with particular reference to cropland weeds. In: Inderjit, Dakshini KMM, Foy CL (eds) Principles and practices in plant ecology: allelochemical interactions. CRC Press, Berks, pp 25-33

61. Franklin KA (2008) Shade avoidance. New Phytol 179:930-944

62. Gagliardo RW, Chilton WS (1992) Soil transformation of 2 $(3 H)$-benzoxazolone of rye into phytotoxic 2-amino-( $3 H)$ phenoxazin-3-one. J Chem Ecol 18:1683-1691

63. Gill HS, Sandhu KS, Mehra SP, Tarlok S (1984) Efficacy of some herbicides for control of weeds in Indian mustard. Indian J Weed Sci 10(7):171-175

64. Goodall J, Witkowski EF, Ammann S, Reinhardt C (2010) Does allelopathy explain the invasiveness of Campuloclinium macrocephalum (pompom weed) in the South African grassland biome? Biol Invas 12:3497-3512

65. Gross EM (1999) Allelopathy in benthic and littoral areas: case studies on allelochemicals from benthic cyanobacteria and submersed macrophytes. In: Inderjit, Dakshini KMM, Foy CL (eds) Principles and practices in plant ecology: allelochemical interactions. CRC Press, LLC, Boca Raton

66. Hammac WA, Pan WL, Bolton RP, Koenig RT (2011) High resolution imaging to assess oilseed species' root hair responses to soil water stress. Plant Soil 339:125-135

67. Haramoto ER, Gallandt ER (2004) Brassica cover cropping for weed management. Renew Agri Food Syst 19(4):187-198

68. Harker KN, O'Donovan JT, Blackshaw RE, Johnson EN, Holm FA, Clayton GW (2011) Environmental effects on the relative competitive ability of canola and small-grain cereals in a directseeded system. Weed Sci 59:404-415

69. Harker KN, Clayton G, Blackshaw R, O’Donovan J, Stevenson F (2003) Seeding rate, herbicide timing and competitive hybrids contribute to integrated weed management in canola (Brassica napus). Can J Plant Sci 83:433-440

70. Harper JL (1977) Population biology of plants. Academic Press, NewYork

71. Hartmann A, Rothballer M, Schmid M (2008) Lorez Hiltner, a pioneer in rhizosphere microbial ecology and soil bacteriology research. Plant Soil 312:7-14

72. Heap I (2013) The international survey of herbicide resistant weeds. www.weedscience.org. Accessed 2 Oct 2013

73. Hedley MJ, White RE, Nye PH (1982) Plant induced changes in the rhizosphere of rape (Brassica napus var. Emerald) seedlings. New Phytol 91:45-56

74. Hertog MGL, Feskens EJM, Hollman PCH, Katan MB, Kromhout D (1993) Dietary antioxidant flavonoids and risk of coronary heart disease: the zutphen elderly study. Lancet 342 : 1007-1011

75. Ho MD, Rosas JC, Brown KM, Lynch JP (2005) Root architectural tradeoffs for water and phosphorus acquisition. Funct Plant Biol 32:737-748

76. Hodge A (2009) Root decisions. Plant Cell Environ 32:628-640

77. Holt JS, Holtum JAM, Powles SB (1993) Mechanisms and agronomic aspects of herbicide resistance. Ann Rev Plant Physiol Plant Mol Biol 44:203-229

78. Hsiao T (1973) Plant responses to water stress. Annu Rev Plant Physiol 24:519-570

79. Jimenez-Osornio JJ (1984) Allelopathic interference in a wild oat (Brassica campestries $\mathrm{L}$ ) and broccoli (Brassica oleracea $\mathrm{L}$ ) intercrop agro-ecosystem. MS Thesis, University of Carlifornia, Santa Cruz

80. Jones E, Jessop R, Sindal B, Hoult A (1999) Utilising crop residues to control weeds. In: Proceedings of 12th Australian Weeds Conferecne Devonport, Australia, pp 373-376

81. Kamh M, Wielser F, Ulas A, Horst WJ (2005) Root growth and $\mathrm{N}$-uptake activity of oilseed rape (Brassica napus L.) cultivars differing in nitrogen efficiency. J Plant Nutr Soil Sci 168:130-137

82. Khanh TD, Chun MI, Xuan TD, Tawata S (2005) The exploitation of crop allelopathy in sustainable agricultural production. J Agron Crop Sci 191:172-184

83. Kirkegaard JA, Gardner P, Desmarchelier J, Angus J (1993) Biofumigation-using Brassica species to control pests and diseases in horticulture and agriculture. In: Proceedings of 16th Australian Research Assembly on Brassicas, Ballarat Victoria

84. Kirkegaard JA, Sarwar M (1998) Biofumigation potential of brassicas. Plant Soil 201:71-89

85. Kirkegaard JA, Sarwar M (1999) Glucosinolate profiles of Australian canola (Brassica napus L.) and Indian mustard (Brassica juncea L.) cultivars: implications for biofumigation. Aust Agric Res 50(3):315-324

86. Knauber DC, Banowetz GM (1992) Phenotypic analysis of dwarf wheat (Triticum aestivum) with altered phytochromemediated growth responses. Plant Physiol 100:1901-1908

87. Kong CH, Wang P, Zhao H, Xu XH, Zhu YD (2008) Impact of allelochemicals exudates of rice on soil microbial community. Soil Biol Biochem 40(18):62-1869

88. Kruidhof HM, Bastiaans L, Kroff MJ (2009) Cover crop residues management for optimizing weed control. Plant Soil 318: 169-189

89. Laine P, Ourry A, Boucaud J (1994) Shoot control of nitrate uptake rates by roots of Brassica napus L.: effects of localized nitrate supply. Planta 196:77-83 
90. Lankau R (2008) A chemical trait creates a genetic trade-off between intra- and interspecific competitive ability. Ecology 89:1181-1187

91. Lemerle D, Lockley P, Koetz E, Diffey S (2013) Herbicide efficacy for control of annual ryegrass (Lolium rigidum Gaud.) is influenced more by wheat seeding density rate than row spacing. Crop Pasture Sci 64:708-711

92. Lemerle D, Luckett DJ, Koetz E, Wu H (2012) Canola (Brassica napus) competition for weed management. Pak J Weed Sci Res 18:327-332

93. Lemerle D, Lockley D, Luckett D, Wu H (2010) Canola competition for weed suppression. In: Proceedings of 17th Australasian Weeds Conference, Christchurch, pp 60-62

94. Lemerle D, Gill GS, Murphy CS, Walker SR, Cousens RD, Mokhtari S, Peltzer SJ, Coleman R, Luckett D (2001) Genetic improvement and agronomy for enhanced wheat competitiveness with weeds. Aust J Agric Res 52:527-548

95. Lemerle D, Blackshaw RE, Smith AB, Potter TD, Marcroft SJ (2001) Comparative survey of weeds surviving in triazine-tolerant and conventional canola crops in south-eastern Australia. Plant Prot Q 16(1):37-40

96. Liebman M, Davis AS (2000) Integration of soil, crop and weed management in low external- input farming systems. Weed Res 40:27-47

97. Lovett JV, Hoult AHC, Christen O (1994) Biologically active secondary metabolites of barley. IV. Hordenine production by different barley lines. J Chem Ecol 20(8):1945-1954

98. Lovett JV, Duffield AM (1981) Allelochemicals of Camelina sativa. J Appl Ecol 18:283-290

99. Mahall BE, Callaway RM (1992) Root communication mechanisms and intra-community distributions of two major desert shrubs. Ecology 73:2145-2151

100. Mahall BE, Callaway RM (1991) Root communication among desert shurbs. Proc Natl Acad Sci USA 88:874-876

101. Mailer RJ, Cornish PS (1987) Effects of water stress on glucosinolates and oil content in the seeds of rape (Brassica napus L.) and turnip rape (Brassica rapa L). Aust J Exp Agric 27:707-711

102. Major DJ, Bole JB, Charnetski WA (1978) Distribution of photosynthates after ${ }^{14} \mathrm{CO}_{2}$ assimilation by stems leaves and pods of rape plants. Can J Plant Sci 58:783-787

103. Matthiessen JN, Kirkegaard JA (2006) Biofumigation and enhanced biodegradation: opportunity and challenge in soilborne pest and disease management. Crit Rev Plant Sci 25:235265

104. Mithen RF (1992) Leaf glucosinolate profiles and their relationship to pest and disease resistance in oilseed rape. Euphytica 63:71-83

105. Mithen RF (2001) Glucosinolates-biochemistry, genetics and biological activity. Plant Growth Reg 34:91-103

106. Mithen RF, Lewis BG, Heaney RK, Fenwick GR (1987) Glucosinolates of wild and cultivated Brassica species. Phytochem 26:1969-1973

107. Mohler CL, Te Asdale JR (1993) Response of weed emergence to rate of Vicia villosa roth and Secale cereale $\mathrm{L}$. residue. Weed Res 33:487-499

108. Mojtahedi H, Santo GS, Wilson JH, Hang AN (1993) Managing Meloidogyne chitwoodi on potato with rapeseed as green manure. Plant Dis 77:42-46

109. Molisch H (1937) Der einfluss einer pflanze auf die andereallelopathie. Fischer, Jena

110. Morgan DC, Smith H (1976) Linear relationship between phytochrome photoequilibrium and growth in plants under simulated natural irradiation. Nature 262:210-212

111. Morra MJ, Kirkegaard JA (2002) Isothiocyanate release from soil-incorporated Brassica tissues. Soil Biol Biochem 34(11): $1683-1690$
112. Muelchen AMR, Parke JL (1990) Evaluation of crucifer manures for controlling Aphanomyces root rot of pea. Plant Dis 74(9):651-654

113. Naylor REL, Lutman PJ (2002) what is weed. In: Naylor REL (ed) Weed management hand book. British Crop Protection Council, Osney mead, New York, pp 19-40

114. Nielsen DC (1997) Water use and yield of canola under dryland conditions in the central great plains. J Prod Agric 10: 307-313

115. Norsworthy JK (2003) Allelopathic potential of wild radish (Raphanus raphanistrum). Weed Technol 17:307-313

116. Norsworthy JK, McClelland M, Griffith G, Bangarwa SK, Still J (2011) Evaluation of cereal and brassicaceae cover crops in conservation-tillage, enhanced, glyphosate-resistant cotton. Weed Technol 25:6-13

117. Numata M (1982) Weed ecological approaches to allelopathy. Biology and Ecology of Weeds. Dr Junk Publisher, Boston, pp $169-173$

118. Nye PH, Tinker PB (1977) Solute movement in the soil-root system. Blackwell, Berkeley

119. Olofsdotter M, Jensen L, Courtois B (2002) Improving crop competitive ability using allelopathy - an example from rice. Plant Breed 121:1-9

120. Olofsdotter M, Navarez D, Rebulanan M, Streibig JC (1999) Weed-suppressing rice cultivars-does allelopathy play a role? Weed Res 39:441-454

121. Parvez MM, Tomita-Yokotani K, Fujii Y, Konishi T, Iwashina T (2004) Effects of Quercetin and its seven derivatives on the growth of Arabidopsis thaliana and Neurospora crassa. Biochem Syst Ecol 32:631-635

122. Pavlychenko TK, Harrington JB (1934) Competitive efficiency of weeds and cereal crops. Can J Res 10:77-94

123. Pedras MSC, Khan AQ, Smith KC, Stettner SL (1997) Preparation, biotransformation, and antifungal activity of methylbenzyldithio carbamates. Can J Chem 75:825-828

124. Pierik R, Mommer L, Voesnek LACJ (2013) Molecular mechanims of plant competition: neighbour detection and response strategies. Funt Ecol 27:841-853

125. Poorter H, Niklas KJ, Reich PB, Oleksyn J, Poot P, Mommer L (2012) Biomass allocation to leaves, stems and roots: metaanalyses of interspecific variation and environmental control. New Phytol 193:30-50

126. Powles SB, Holtum JAM (1994) Herbicide resistance in plants: biology and biochemistry. Lewis, Boca Raton

127. Purvis C, Jessop R, Lovett J (1985) Selective regulation of germination and growth of annual weeds by crop residues. Weed Res 25:415-421

128. Putnam AR, DeFrank J (1983) Use of phytotoxic plant residues for selective weed control. Crop Prot 2:173-181

129. Putnum AR, Tang CS (1986) Allelopathy: state of the science. In: Putnum AR (ed) The science of allelopathy. Wiley, New York, pp 1-14

130. Radosevich S, Holt J, Ghersa C (1996) Physiological aspects of competition. In: Radosevich S, Holt J, Ghersa C (eds) Weed ecology: implications for management, 2nd edn. Wiley, New York, pp 217-287

131. Raymer PL (2002) Canola: An emerging oilseed crop. Trends in new crops and new uses. ASHS Press, Alexandria

132. Rice EL (1974) Allelopathy, 1st edn. Academic, Orlando

133. Rice EL (1984) Allelopathy, 2nd edn. Academic, Orlando

134. Rice EL (1995) Biological control of weeds and plant disease. In: Rice EL (ed), Advances in applied allelopathy, University of Oklahoma Press, Norman

135. Rizvi SJIH, Haque H, Singh VK, Rizvi V (1992) A discipline called allelopathy-allelopathy: basic and applied aspects, Chapmann \& Hall Publishers, London 
136. Rose SP, Bell JM (1982) Reproduction of mice fed low erucic acid rapeseed oil contaminated with weed seed oils. Can J Anim Sci 62:617-624

137. Rose T, Rengela Z, Ma Q, Bowden JW (2009) Phosphorus accumulation by field-grown canola crops and the potential for deep phosphorus placement in a Mediterranean-type climate. Crop Pasture Sci 60:987-994

138. Rose TJ, Renge Z, Ma Q, Bowden JW (2007) Differential accumulation patterns of phosphorus and potassium by canola cultivars compared to wheat. Plant Nutr Soil Sci 170:404-411

139. Roshdy AM, Shams El-Din GM, Mekki BB, Elewa TAA (2008) Effect of weed control on yield and yield components of some canola varieties (Brassica napus L.). Am Euras J Agric Env Sci $4(1): 23-29$

140. Rumberger A, Marschner P (2003) 2-Phenylethylisothiocyanate liberated by living canola roots affects the microbial community and composition in the rhizosphere. Soil Biol Biochem 35:445-452

141. Rumberger A, Marschner P (2004) 2-Phenylethylisothiocyanate concentration and bacterialcommunity composition in the rhizosphere of field grown canola. Funct Plant Biol 31(6):623-631

142. Sang JP, Minchinton IR, Johnstone PK, Truscott JW (1984) Glucosinolate profiles in the seed, root and leaf tissue of cabbage, mustard, rapeseed, radish and swede. Can J Plant Sci 64:77-93

143. Sarwar M, Kirkegaard JA (1998) Biofumigation potential of brassicas. II. Effect of environment and ontogeny on glucosinolate production and implications for screening. Plant Soil 201:91-101

144. Scott RK, Ogunremi EA, Ivins JD, Mendham NJ (1973) The effect of sowing date and season on growth and yield of oilseed rape (Brassica napus). J Agric Sci 81:277-285

145. Seal AN, Pratley JE, Haig T, Lewin LG (2004) Screening rice varieties for allelopathic potential against arrowhead (Sagittaria montevidensis), an aquatic weed infesting Australian Riverina rice crops. Aust J Agric Res 55:673-680

146. Seal AN, Pratley JE, Haig T (2008) Can results from a laboratory bioassay be used as an indicator of field performance of rice. Aust J Agric Res 69:183-188

147. Seigler DS (1996) Chemistry and mechanism of allelopathic interactions. Agron J 88:876-885

148. Semchenko M, Zobel K, Heinemeyer A, Hutchings MJ (2008) Foraging for space and avoidance of physical obstructions by plant roots: a comparative study of grasses from contrasting habitats. New Phyiol 179(4):1162-1170

149. Sing HP, Batish DR, Kohli RK (2001) Allelopathy in agroecosystem: an overview. J Crop Prod 4:1-41

150. Smith BJ, Kirkegaard JA (2002) In vitro inhibition of soil microorganisms by 2-phenylethyl isothiocyanate. Plant Pathol 51:585-593

151. Stowe LG (1979) Allelopathy and its influence on the distribution of plants in an Illinois old-field. Ecology 67:1065-1085

152. Strong WM, Soper RJ (1974) Phosphorus utilization by flax, wheat, rape, and buckwheat from a band or pellet-like application I. Reaction zone root proliferation. Agron J 66:597-601

153. Thurling N (1974) Morphological determinants of yield in rapeseed (Brassica campestries and Brassica napus) growth and morphological characters. Aust Agri Res 25:697-710
154. Tilman D, Pacala S (1997) The mainintaince of species richness in plant communties. Species Diversity in Ecological Communities: historical and geographical perspectives. University Press, Chicago, pp 13-25

155. Tomass P (1992) Canola grower manual. Canola Council of Canada, Winnipeg

156. Uremis I, Arslan M, Sangun MK, Uygur V, Isler N (2009) Allelopathic potential of rapeseed cultivars on germination and seedling growth of weeds. Asian J Chem 21:2170-2184

157. Uren NC (2000) Types, amount, and possible functions of compounds released into the rhizosphere by soil-grown plants. In: Pinton R, Varanini Z, Nannipieri P (eds), The Rhizosphere: biochemistry and organic substances at the soil-plant interface. Marcel Dekker, New York, vol 57, pp 233-266

158. Vaughn SF, Berhow MA (1999) Allelochemicals isolated from tissues of the invasive weed garlic mustard (Alliaria petiolata). J Chem Ecol 25(11):2495-2504

159. Vaughn SF, Boydston RA (1997) Volatile allelochemicals released by crucifer green manures. J Chem Ecol 23:2107-2116

160. Walker TS, Bais HP, Grotewols E, Vivanco JM (2003) Root exudation and rhizosphere biology. Plant Physiol 132(1):44-51

161. Weiss EA (1983) Rapeseed. Oilseed Crops. Longman Inc, New York, pp 161-215

162. Weston LA, Ryan PR, Watt M (2012) Mechanisms for cellular transport and release of allelochemical from plant roots into the rhizosphere. J Exp Bot 54:1-10

163. Weston LA (1996) Utilization of allelopathy for weed management in agroecosystems. Agron J 88:860-866

164. Weston LA, Duek SO (2003) Weed and crop allelopathy. Crit Rev Plant Sci 22(3-4):367-389

165. Wilson JB (1988) Shoot competition and root competition. J Appl Ecol 25:279-296

166. Wink M (1988) Plant breeding: importance of plant secondary metabolites for protection against pathogens and herbivores. Theor Appl Genet 75(2):225-233

167. Wink M (2003) Evaluation of secondary metabolites from an ecological and molecular phylogenetic perspective. Phytochem 64:3-9

168. Worthington M, Reberg-Horton C (2013) Breeding cereal crops for enhanced weed suppression: optimizing allelopathy and competitive ability. J Chem Ecol 39:247-256

169. Wu H, Pratley J, Lemerle D, Haig T (2000) Evaluation of seedling allelopathy in 453 wheat (Triticum aestivum) accessions against annual ryegrass (Lolium rigidum) by the equalcompartment-agar method. Aust J Agric Res 51:937-944

170. Wu J, Muir AD (2008) Comparative structural, emulsifying, and biological properties of 2 major canola proteins, cruciferin and napin. J Food Sci 73:210-216

171. Zand E, Beckie H (2002) Competitive ability of hybrid and open-pollinated canola (Brassica napus) with wild oat (Avena fatua). Can J Plant Sci 82:473-480

172. Zeng RS, Mallik AU, Setliff E (2003) Growth stimulation of ectomycorrhizal fungi by root exudates of Brassicaceae plants: role of degraded compounds of indole glucosinolates. J Chem Ecology 29(6):1337-1355

173. Zimdahl RL (2007) Fundamentals of weed science. Academic Press, London 